This is the accepted version of an article published by Elsevier in Pacific-Basin Finance Journal Vol. 46 Part A., 124-

140. Published version available from: https://doi.org/10.1016/j.pacfin.2017.09.007

Accepted version downloaded from SOAS Research Online: http://eprints.soas.ac.uk/24654/ under CC-BY-NC-ND 4.0 International Licence

\title{
Why do firms adopt stock options and who benefits? A natural experiment in China
}

\author{
Lin Jiang - School of Finance and Management, SOAS University of \\ London \\ Gerhard Kling - School of Finance and Management, SOAS University of \\ London \\ Hong Bo - School of Finance and Management, SOAS University of \\ London \\ Ciaran Driver - School of Finance and Management, SOAS University of \\ London
}

\begin{abstract}
A regulatory change in 2006, permitting equity compensations in China, offers a natural experiment to investigate drivers and outcomes of stock options. There are two unique features. First, adoption of stock options occurred rapidly com- pared to the US, where stock options have been around for more than 100 years with periods of high (1990s) and low (before 1950s) adoption. Second, stock options have been issued by stateowned enterprises (SOEs), an unusual aspect. This study analyzes all listed companies in China from 2004 to 2014, testing two competing theories: optimal contracting and managerial power. If managers own more equity, if the CEO also serves as board chairman and if compensation committees exist, managers are more likely to receive stock options. Ownership type and firm characteristics are also essential factors in granting stock options. In non-SOEs, evidence suggests that controlling shareholders award stock op- tions less frequently but if they do they seem to induce managers to collude in tunneling. Applying a propensity score matching approach to account for an alleged self-selection bias, we do not observe any improvements in firm perfor- mance or shareholder value after stock options have been issued. Accordingly, managerial power seems to be the predominant driver for the introduction of stock options. Hence, managerial accountability and better disclosure are es- sential to ensure that stock options do contribute to value creation.
\end{abstract}

Keywords: Stock options, managerial power, optimal contracting 


\section{Introduction}

On $31^{\text {st }}$ of December 2005, the China Securities Regulatory Commission (CSRC) released the 'Measures for the Administration of Stock Incentive Plans of Listed Companies', permitting equity compensations. Hence, China offers a natural experiment where the adoption of stock options occurred in a 10-year narrow window as compared to the US, where stock options have been used for more than 100 years with varying degrees of popularity. Given this unique setting, our study can explore early and late adopters of equity compensations from 2004 to 2014, revealing their motives and assessing whether stock options enhanced firm performance and shareholdervalue.

Having been widely adopted and analyzed in developed countries, stock op- tions have long been regarded as an incentive mechanism to align CEOs' and shareholders' interests and to alleviate moral hazard problems (Yermack, 1995; Core and Guay, 1999). However, these mechanisms rely on a market-basedgovernance system, where efficient stock markets reflect firm performance accu- rately. In spite of a long history of regulatory changes (Gao and Kling, 2006)and signs of improved efficiency (e.g. in the context of calendar anomalies, Kling and Gao (2005)), Chinese stock markets are not yet at par with their Westerncounterparts, and governance issues remain (Gao and Kling, 2008; Kling and Gao, 2008). Assessing why some firms adopted stock options, while others did not, and identifying who ultimately benefited is crucial in evaluating China's recent compensation reform.

Chinese stock options have been rarely studied with only a few excep- tions (Conyon and He, 2011; Fang et al., 2015), as it is a relatively new phe- nomenon. Thus, it has remained unclear what affects the decision to introduce stock options and whether desired outcomes can be realized. Despite ongoing market-oriented reforms, China still exhibits higher ownership concentration, 
less developed stock markets and weaker legal protections compared to Western economies. According to our data, over $62 \%$ of the listed firms have a con- trolling shareholder who owns over $30 \%$ of the firms' outstanding shares, and the average ownership of controlling shareholders of all listed firms is $37 \%$. By contrast, it is rare for investors to own more than $10 \%$ of the outstanding shares in Anglo-Saxon economies (Conyon and He, 2011). Furthermore, the state still plays a significant role in the economy through state-ownership, administrative governance and regulations (Gao and Kling, 2012). This unique institutional setting casts doubts on the real motivations and impacts of stock options. Why do state-controlled enterprises (SOEs) or companies dominated by a principal shareholder need stock options? And most importantly, is there any evidence on their value-enhancing capabilities.

Empirical studies on equity compensation in developed countries yield con- flicting results. Yermack (1995) indicates that agency or financial contracting theories cannot explain the pattern of stock options awarded to CEOs in the US. He tests nine hypotheses based on agency theory, only finding support for two. More recently, based on an US sample from 1982 to 2001, Kim and Ouimet (2014) documents that the number of employees and the size of options influ- ence the benefits of incentives schemes. They argue that stock options are most effective in firms with a small number of employees and where options account for a small fraction of firm value. In contrast, large equity compensation pack- ages are often implemented for non-incentive purposes and thus do not improve firm performance.

Previous literature on Chinese executive compensation has mainly focused on cash payments (Firth et al., 2006; Chen et al., 2010, 2011), while equity compensation has been largely omitted due to data availability - except in the case of Hong Kong. Yet, the institutional background of Hong Kong is quite 
different from mainland China. Chen et al. (2013) analyze the stock options of red chip firms listed in Hong Kong and argue that stock options granted by state-controlled red chip firms are not effective. For mainland China, Chen et al. (2010) based on the managerial power perspective argue that CEO duality and CEO shareholding entrench managers to extract firms' assets; however, they only analyze cash compensation. Conyon and He (2012) investigate the deter- minants of CEOs' share-ownership and equity compensations based on agency theory. ${ }^{1}$ They argue that there is little evidence that governance variables in- fluence CEO pay. By contrast, a more recent study by Fang et al. (2015) yield conflicting results while investigating the employee stock options covering almost the same period. They find no relationship between executive stock ownership and options granted and report a negative correlation between board size and stock options. They also argue that employee stock options in China improved firm performance, and that better corporate governance enhanced this positive impact. Therefore, the understanding of equity compensations in China is far from clear, and it is essential to evaluate recent data.

This paper attempts to fill this gap by addressing the following research ques- tions. First, why and under what circumstances did Chinese firms adopt stock options? Particularly, are stock options in Chinese firms an incentive device to solve agency problem or just a form of managerial discretion? Prior literature (Yermack, 1995; Conyon and He, 2012) is mainly based on the optimal con- tracting approach arguing that incentive compensation aligns shareholders' and managers' interests. By contrast, Bebchuk and Fried (2003) propose the man- agerial power approach arguing that compensation arrangements themselves could be part of an agency problem, because managers are able to exert influ-

\footnotetext{
${ }^{1}$ Conyon and He (2012) include stock options, restricted stock and share appreciation rights as equity compensation in their study.
} 
ence over the pay arrangements to extract private benefits. This paper tests both approaches. Second, do corporate governance and ownership structure af- fects stock options? As discussed earlier, the Chinese institutional background is quite different from other developed countries despite continuous reforms. Fi- nally, and most importantly, do stock options improved firm performance and shareholder value? Put differently, who benefits from stock options, managers or shareholders?

To address these research questions, we analyze a comprehensive database of Chinese listed firms from 2004 to 2014, covering the complete and most recent period during which stock options have been adopted. There are analytical prob- lems related to an alleged self-section bias as well-performing firms enjoy better market valuation, increasing the propensity to grant stock options (Bergman and Jenter, 2007). These firms are more likely to present better post-event firm performance due to positive autocorrelation between past and present perfor- mance. To address this potential bias, we apply a propensity score matching method, comparing firms that adopted stock options to their matched control group and the unmatched sample.

Our study yields the following insights. First, managerial power plays a sig- nificant role in stock options granted by Chinese firms. Our results indicate that managers are more likely to be awarded with stock options if they hold higher equity shareholdings in the firm, if the firm has a compensation committee and if the CEO is also the chairman of the board of directors. Second, ownership type matters. In line with previous literature (Conyon and He, 2011; Chen et al., 2010), we find that state controlled firms are less likely to adopt stock options. However, we do not observe a significant impact of ownership concentration, which is in line with Fang et al. (2015) but contradicts Conyon and He (2012). Third, firms with younger executives are more likely to award their managers 
with stock options. Fourth, firm characteristics are also essential in the decision to issue stock options. We show that financial leverage, firm size and growth opportunities are important factors in shaping executive pay packages. Prior firm performance also influences stock options positively. In addition, high tech- nology firms are more likely to grant options. Finally, controlling shareholders play a role in non-state controlled firms. Non-SOEs controlled by a shareholder tend to issue stock options less frequently as incentives should matter less given the direct control. Yet, if controlled firms issue stock options, tunneling seems to increase, suggesting that stock options are awarded to managers to induce them to collude with the principal shareholder.

Our propensity score matching shows that stock options do not improve firm performance or stock returns, violating the argument of the optimal contracting approach that equity compensation helps to resolve agency problems. Hence, it seems likely that powerful managers influence pay arrangements, making execu- tive compensations ineffective. Stock options are, to some extent, rather a form of managerial rent exaction than an incentive to maximize shareholder value.

Our study makes several contributions. First, we present the most recent evidence on Chinese stock options since their introduction in 2006. Second, this study is the first attempt to analyze Chinese stock options based on both approaches, optimal contracting and managerial power, which provides a dif- ferent perspective on executive pay dominated by agency theory. Third, our study controls for an alleged self-section bias using a propensity score matching, which provides unbiased estimates of post-event firm performance. Finally, the Chinese context allows us to study the early adoption of incentive plans, which is not possible to observe in developed markets.

Our results provide several policy implications. With reform deepening, managers have received substantial power over business operations. However, 
there are no adequate monitoring mechanisms in position to avoid managerial self-dealing activities. Therefore, increasing financial transparency and informa- tion disclosure, especially more detailed disclosure on executive compensation, are called for to improve managers' accountability. Furthermore, Chinese mar- kets also require more legal protection towards shareholders, especially minority shareholders, to prevent them from being harmed by self-dealing managers.

The remainder of the paper is organized as follows. Section 2 describes the institutional background. Section 3 discusses the underlying theories. Section 4 describes data collection and methodology. Results are discussed in Section 5 followed by a discussion and conclusion.

\section{Institutional background}

Compared to Anglo-Saxon economies, relatively little is known about ex- ecutive compensation and CEO equity incentives in China (Firth et al., 2006; Conyon and He, 2011). This section briefly describes the institutional back- ground in China and how it influences our theoretical and empirical analysis.

China has been reforming its economy since 1978, and the marketoriented reform has largely influenced the evolution of Chinese executive compensation (Chen et al., 2011). Prior to these reforms, the Chinese economy was controlled centrally, and all enterprises were state owned. The main objective of these state-owned enterprises (SOEs) was to fulfill political targets such as providing employment to maintain social stability. All profits were repatriated to the state. There were neither incentive schemes nor profit sharing schemes for managers. Reforms in the 1980s featured basic profit retention and profit sharing schemes to incentivize managers (Sun and Tong, 2003). At this stage, a preliminary managerial resource allocation system has been brought forward, and managers began to take some responsibilities for decision making, which allowed them to 
control a more substantial amount of economic resources (Groves et al.,

1994). With the reopening of the two stock exchanges in Shanghai and

Shenzhen in the 1990s, the corporatization of SOEs dominated the

following years. Through public listing in stock exchanges, SOEs were expected to transfer from sole state proprietorships to public shareholding companies, which is the main form of modern firms in developed countries with diversified ownership and inde- pendent decision making.

The main targets of the corporatization were (1) to change state ownership to publicly traded ownership; (2) to separate the state from business operations so that enterprises can achieve full autonomy over business decisions; (3) to improve managerial incentives by linking executive compensation to firm performance (Chen et al., 2011). In 2005, the Chinese government brought forward the non-tradable shares reform to partially pri- vatize SOEs with the aim to deepen the reform and to effectively incentivize managers. Although the state has still retained sufficient shares to maintain voting control (Firth et al., 2006; Chen et al., 2011), managers have acquired new powers and autonomy within firms than ever before. Finally, on December 31th, 2005, the China Securities Regulatory Commission (CSRC) released the 'Measures for the Administration of Stock Incentive Plans of Listed Companies' encouraging the adoption of equity incentive schemes with the aim to better incentivize managers.

However, there are no appropriate mechanisms currently in position to pre- vent managers from abusing their new powers (Chen et al., 2011). According to He (1998), many mangers in Chinese listed firms have extracted private benefits through their newly gained independence. In contrast to developed economies with dispersed ownership, Chinese listed firms are characterized by high own- ership concentration, dominant shareholders and insider rent extraction (Chen, 2005; Firth et al., 2006; Gao and Kling, 2008). Furthermore, current corporate 
governance mechanisms, such as adequate financial transparency, information disclosure and protection towards minority shareholders, are not in place (Chen, 2005; Liu, 2006; Gao and Kling, 2012). These systematic weaknesses enable mangers to reap private benefits at the expense of shareholders.

Although many policies and regulations ${ }^{2}$ have been brought forward to re- form the corporate governance system, the underdeveloped external monitoring mechanisms and stock markets cast doubt on the real effects of the reforms.

\section{Underlying Theories}

There are two main theoretical views regarding executive compensation, the optimal contracting approach based on agency theory, and the managerial power perspective. Given the peculiarities of the Chinese governance system and a large number of reforms, it seems to be likely that both approaches might play a role in explaining the adoption of stock options. Agency theory has been the dominant view from a policy perspective as most reforms have been aimed at reducing agency costs. However, the question as to whether managers have become too powerful points to the alternative approach. Hence, we test both theoretical perspectives. The following section briefly outlines the basic agency problem and explains theoretical predictions. We identify variables for each theoretical approach that could affect the adoption of stock options. Empirically, it is challenging to discriminate between the two theoretical approaches as some variables could be regarded as proxies for both theories. Hence, it is crucial

\footnotetext{
2e.g., the CSRC revised the 'Format and Content of Information Disclosure', requiring companies to disclose the total compensation of each individual director, supervisor and senior manager. In 2013, the CSRC again revised the 'Content and Format of the Annual Report of GEM (Growth Enterprise Market)' listed companies and the GEM companies are now required to disclose their decision-making process and the determinants of compensation for directors, supervisors and senior managers, in addition to the actual payments made to each of them. In 2009, the Ministry of Human Resources and Social Security (MHRSS) issued the 'Further Guidance to Standardize Executives Compensation Contracts in Central-government- controlled Companies (The
} 
This is the accepted version of an article published by Elsevier in Pacific-Basin Finance Journal Vol. 46 Part A., 124140. Published version available from: https://doi.org/10.1016/j.pacfin.2017.09.007

Accepted version downloaded from SOAS Research Online: http://eprints.soas.ac.uk/24654/ under CC-BY-NC-ND 4.0 International Licence

Guidance)'. 
in our empirical strategy to identify whether firm performance and shareholder value actually improved after the introduction of stock options. An improvement would signal that agency conflicts were resolved through the incentive scheme. In contrast, if firms did not perform better, it would suggest that managers would be the only beneficiaries.

\subsection{The optimal contracting approach}

The agency problem is at the heart of modern firms (Jensen and Meckling, 1976) and its essence is the separation of ownership and control (Shleifer and Vishny, 1997). In general terms, investors and managers sign a contract specify- ing what managers do in terms of investment and how profits are to be allocated. However, many unforeseen circumstances make a complete contract infeasible. Furthermore, due to investors' lack of professional qualifications and access to information, managers maintain substantial residual control rights over how to allocate investors' funds. Managers therefore have both the ability and incentive to take discretionary activities $^{3}$ to pursue private benefits of control (Grossman and Hart, 1988). Executive compensation, among various corporate governance mechanisms, has been designed to address this misalignment of interests.

Incentive compensation $^{4}$ has been deemed to incentivize managers to select and implement actions to increase shareholder value (Jensen and Murphy, 1990). This view has been labeled 'optimal contracting approach' which sees compen- sation arrangements as 'an arm's length contract' to align managers' interests with those of shareholders. Under this approach, stock options, an important form of incentive compensation, has become increasingly popular. According

\footnotetext{
${ }^{3}$ Managerial expropriation can take various forms. For example, managers can directly abscond with money in a pyramid structure. It can also take more elaborate forms such as transfer pricing on firms' output or even assets and unreasonable high executive compensation. Other manifestations include expanding firms beyond rational, pursuing pet projects and resisting being replaced for poor management.

${ }^{4}$ Incentive contracts can take various forms such as share ownership, stock options and a threat of dismissal in case of poor performance (Shleifer and Vishny, 1997)
} 
to a survey by Core et al. (2003), over $70 \%$ of CEOs have received new option grants, and options have become a major component of CEOs' compensation in the US by 1994. A number of previous studies in developed markets that ana-lyze the adoption of stock options are largely based on the optimal contracting approach (Core et al., 2003; Jensen and Murphy, 1990; Yermack, 1995).

\subsection{The managerial power approach}

As opposed to the optimal contracting approach, Bebchuk and Fried (2003) propose that the design of compensation arrangement is part of the agency problem rather than a solution to it. They argue that executives have substantial influence over their own pay. One of the most direct ways to extract rents is to set themselves favorable pay arrangement. This approach in the context of executive compensation has been labeled managerial power approach.

Stock options have long been argued to provide incentive to managers since they link managers' wealth directly to stock performance, but options fail to fil- ter out stock price increases unrelated to mangers' own performance and efforts. This is particularly the case when the whole industry or the market experiences an economic boom or a phase of overvaluation. In this case, even managers that perform poorly can get a large amount of pay-back through stock options. Hence, the 'windfall' feature of stock options makes them more favorable to managers than shareholders.

In spite of these shortcomings, stock options that favor managers are still common in many countries. Bebchuk and Fried (2003) explain this phenomenon as designing compensation schemes that benefit executives without being per-ceived as clearly unreasonable or flawed. There are ways to replace stock options with 'reduced-windfalls' options. For instance, index options, which link the ex- ercise price to a market-wide or a sector-specific index, can differentiate between firm performance and wider changes in markets or industries. Moreover, cer- 
tain vesting conditions can limit the 'windfall-effect'. They have, however, been largely ignored. In China, some stock options have vesting conditions such as meeting predetermined performance criteria (usually based on return on eq- uity). Yet, at-the-money options are still the predominant form, and vesting conditions can be somewhat ambiguous and flexible.

In summary, the managerial power approach contends that powerful man- agers are more likely to be awarded with favorable pay arrangement such as stock options due to their influence over the compensation setting process.

\subsection{Discriminating between the two theories}

To test the two theories, our empirical strategy needs to identify discriminat- ing variables, which is challenging as some variables are related to both theories. In line with our research questions, we focus on a pre-event analysis, which de- termines factors that explain the adoption of stock options, and a post-event analysis, which evaluates the impact of stock options on firmperformance.

\subsubsection{Pre-event analysis: Determinants of stock options}

The optimal contracting approach suggests that managerial direct stock ownership constitutes a substitute to stock options, as it provides the most directlink between shareholders' and CEOs' wealth (Murphy, 1999; Berle and Means, 1991; Jensen and Meckling, 1976). Therefore, in line with agency theory, stockoptions are more likely to be adopted if managers hold smaller portion of stocks.Consequently, if the optimal contracting approach applies to the Chinese case, we would observe a negative impact of managerial shareholding on stock op- tions granted. Interestingly, the role of managerial stock ownership can also beviewed from the managerial power approach, yielding a different prediction. Be-cause stock ownership endows managers with direct voting rights, managers have more power over firms' decisions. Given the Chinese institutional background, 
the ongoing reform has substantially reduced government intervention in firms' operations, increasing managers' power in allocating resources. Although ex- ecutives' stock ownership is designed to align the interests of shareholders and managers (alignment effect), the entrenchment effect dominates when mangers' equity stake rises (Fama and Jensen, 1983). Consequently, under the manage- rial power approach, we predict that managerial stock ownership has a positive impact on the adoption of stock options.

Controlling shareholders are also important actors in the principal-agent problem. Shleifer and Vishny (1997, p.754) contend that "large shareholders address agency problems in that they have both a general interest in profit maximization, and enough control over the assets of the firm to have their in-terest respected". Therefore, agency theory predicts a lower propensity to issue stock options with the presence of a controlling shareholder. However, large shareholders do not always bring benefits in the sense of enhancing shareholder value. According to Claessens et al. (2002), firm values fall and entrenchment ef-fects dominate when control rights of the largest shareholder exceed its cash-flow rights. Hence, the controlling shareholder has an incentive to purse private ben-efits at the expense of minority shareholders through various forms of tunneling (Johnson et al., 2000). This is especially the case in China where legal systems and corporate governance are not yet effective in protecting minority shareholders' interests. Furthermore, the controlling shareholder is also the manager in many instances in Chinese firms, and tunneling is usually achieved through col-lusion between controlling shareholders and executives (Wang and Xiao, 2011).Given the aforementioned shortcomings of stock options, it is likely that they are awarded to induce managers to collude with controlling shareholders. Thus, the Type II agency problem, i.e. the conflict between controlling shareholderand minority shareholder, implies a positive association between the presence 
of a controlling shareholder and the adoption of stock options.

Similarly, ownership concentration also matters. Since dispersed ownership is common in most developed countries, minority shareholders usually lack the ability and incentive to monitor managers' actions. Therefore, monitoring by investors is easier if control is concentrated in the hands of a small number of investors. Since shareholders' monitoring and incentive contracts are substitutes in solving agency problems, it is predicted that stock options are less likely to be adopted by firms with higher ownership concentration. The managerial power approach results in the same prediction as managers in firms with high ownership concentration exercise less influence.

State control is a special type of ownership structure, where the state ex- ercises control over firms. In China, bureaucrats possess control rights, but no corresponding cash flow rights because cash flow rights of SOEs are related to government budgets. Moreover, SOEs also pursue political objectives rather than shareholder value maximization, such as offering job opportunities to en- hance social stability. Therefore, bureaucrats are less concerned about opti- mizing firm performance. SOEs thus lack the incentive to adopt stock options. Additionally, most managers in SOEs are appointed by the government and are rewarded with political promotions by fulfilling political targets (Conyon and He, 2011). Hence, managers are less sensitive to incentive compensation schemes than their counterparts in private firms. In summary, both, the princi- pal (the state) and the agent (managers) in SOEs are less concerned with profits than those in private entities. SOEs, therefore, are predicted to be less likely than private firms to grant stock options. Arguably, managers in SOEs are less powerful due to direct state control and monitoring, e.g. the Stateowned As- sets Supervision and Administration Commission of the State Council (SASAC) exercises control over the largest SOEs (Gao and Kling, 2012). Hence, the man- 
agerial power approach suggests a similar negative impact of state ownership on the propensity to issue stock options.

Setting up compensation committees is originally a mechanism to enhance corporate governance under the optimal contracting approach. These commit- tee employ compensation professionals to provide advice on pay and the designof effective executive compensation packages. Better internal governance mech-anisms should act as a substitute to stock options. Based on the managerial power approach, however, compensation committees use their discretion to ben- efit CEOs, since CEOs can influence the appointment of members of the com-mittee. Furthermore, setting a compensation arrangement that harms CEO'sinterests could also affect committee members by decreasing the probability tobe hired again. This is especially the case in China where guanxi. i.e. social capital and networks, is an important principle in business relations. Previousliterature (Gillan, 2001) also argues that compensation consultants tend to fa-vor CEOs by justifying high level of executive pay through providing favorable compensation data. Murphy (1999) states that executive pay increases due toa combination of helpful compensation consultants and sympathetic boards.

An effective board structure is expected to reduce agency problems through appropriate monitoring of management under the optimal contracting approach. The managerial power approach predicts that compensation will be more favor-able to managers when the board is relatively weak and inefficient. The board isregarded as weak when it is too large because a free-rider problem emerges ham-pering the monitoring role of board members (Yermack, 1996). So large boards based on both theories should increase the propensity to issue stock options. When the CEO or general manager also serves as board chairman, the boardis also assumed to be less efficient. This is because combining the two postswill potentially increase CEOs' power and thus reduce boards' independence 
(Conyon and He, 2012). We therefore conjecture that if the managerial power approach applies to China, we would observe a positive correlation between board size, duality and stock option granted respectively.

Executive's age has also been regarded as an important factor. Different from conventional cash compensation, stock options benefit receivers over a relatively long period of time. In the US, stock options are usually vested over a 10-year period. In China, the average vesting period is 4 to 5 years as discussed in the empirical analysis. Older executives, especially close to retirement, would prefer cash compensation to stock options. By contrast, stock options would provide more incentive to younger executives because they have enough time in post to enjoy benefits. We therefore predict that executive's age is negatively related to the adoption of stock options, which is mainly based on the optimal contracting approach. The link between managerial power and age seems to suggest an opposite effect as older executives might be more powerful. Yet, this effect is mitigated by the argument that older CEOs still prefer cash to equity compensations.

There are also firm level factors that affect the adoption of stock options. Capital structure, measured by financial leverage, affects stock options as debt holders monitor managers' decision making, e.g. contractual obligations linked to performance measures (Shleifer and Vishny, 1997). A higher proportion of debt, therefore, enables creditors to have more power to monitor managers to prevent them from pursuing over-risky projects that could potentially hurt creditors' interests. An easy way to reduce managers' incentive to take on these risky projects is to lessen the pay-performance sensitivity of executive compensation. We predict a negative impact of financial leverage level on stock options.

Large firms are deemed to face more difficulties and problems in manage- 
ment (e.g. complexity), their managers thus need more incentives. As for the firms that are in a growing stage, managers usually have more information than shareholder on firms' growth opportunities. In order to reduce the agency prob- lem caused by information asymmetry, managers in high-growth firms are more likely to be awarded with stock options. Theoretically, the managerial power ap- proach would suggest similar predictions in the context of firm size and growth opportunities.

Previous firm performance also affects stock option granted. Here, the two theories suggest opposing partial impacts, enabling us to discriminate between them. Agency theory implies that under-performing firms are more likely to adopt stock options to incentivize managers, leading to a negative partial impact of previous firm performance. In contrast, under the managerial power theory, firms with better prior firm performance are more likely to grant options because managers have a higher probability to benefit from the increase in market value driven by good performance.

Finally, high-technology firms are predicted to be more likely to grant options. Previous work (Core et al., 2003) shows that the use of stock optionsvaries across industries. High-technology firms rely more on human resources,especially technicians with key skills. Providing higher incentives to attract andretain professionals is essential. For instance, as the leading high-technologyfirm in China, Alibaba offered over 490 million dollars to its employee stock ownership plans (ESOPs). The two theories do not lead to different predictionsin the context of industry-specific effects.

\subsubsection{Post-event analysis: Outcome of stock options}

Distinguishing between the two theoretical perspectives is challenging in the pre-event analysis because many explanatory variables are predicted to exhibit similar partial impacts on the adoption of stock options. Yet, three variables 
stand out. First, managerial stock ownership is a substitute for stock options under the optimal contracting approach - but suggests more managerial power. So optimal contracting suggests a negative impact, while managerial power pre- dicts a positive impact. Second, compensation committees are supposed to improve internal governance making stock options less likely based on the op- timal contracting approach, whereas they might increase equity compensations in line with managerial power. Third, poor past performance increases the like- lihood of stock options under agency theory - contrary to the managerial power argument.

The post-event analysis offers an easier theoretical approach to distinguish between the two theories. If the optimal contracting approach is valid, one should expect that stock options mitigate agency conflicts, resulting in better firm and stock market performance after the issue. If the managerial power approach is true, one should not expect any performance improvements after issues. In spite of its theoretical clarity, empirically establishing the post-event outcome of stock options is difficult due to the self-section effect, requiring a propensity score matching (or similar) approach.

\section{Data and methodology}

\subsection{Data collection}

Our sample is an unbalanced panel dataset comprising all firms listed on the Main Board (both Shanghai and Shenzhen), the Small and Mediumsized En-terprises (SME) Board and the Growth Enterprises Market (GEM) Board from2004 to 2014. We collect our data from the China Stock Market and Accounting Research (CSMAR) database, which provides financial and stock market data. Additional data such as details of each stock option plan is hand collected from the official websites of the Shanghai and Shenzhen stock exchanges that are 
authorized by the CSRC for public information disclosure.

Our sample selection process is as follows. Among the 21,349 firmyear observations, 482 adopted stock option plans. Since we require non missing data for the propensity score matching, it reduces our sample size of the so- called treatment group, i.e. firms with stock options, to 396 observations.

Our sample is unique in the following aspects. First, it includes equity compensation that has been largely ignored due to data availability by prior executive compensation research in China (Conyon and He, 2011; Cao et al., 2011). Second, our data covers a more complete and recent sample period from 2004 to 2014 while prior research on China only uses data before 2011 (Conyon and He, 2011; Fang et al., 2015). Finally, compared with studies in the US and UK, our sample is unique because we look at early adoption of incentive plans, which is not possible to observe in developed markets as most firms use incentives since the 1950s.

\subsection{Logistic regressions for the pre-event analysis}

In line with prior research (Conyon and He, 2011; Chen et al., 2013) and our theoretical considerations, logistic models explain the binary variable ISSUE,

i.e. whether a firm introduces stock options or not as shown in equation (1), where $i=1,2, \ldots, N$ refers to firms and $t=1,2, \ldots, T$ indicates years. The error term $E_{i t}$ has the usual properties, i.e. i.i.d. distributed with mean zero and constant variance. However, our empirical models also considers random- effects, i.e. including a firm-specific error term into (1) and fixed-effects models, 
including industry and year-specific effects.

$$
\begin{aligned}
\text { ISSUE }_{i t}= & \alpha+\beta_{1} \text {HITECH }_{i t}+\beta_{2} L_{E V_{i t}+\beta_{3} S I Z E_{i t}} \\
& +\beta_{4} \text { GROWTH }_{i t}+\beta_{5} \text { ROE }_{i t}+\beta_{6} R E T U R N_{i t}+\beta_{7} \text { COMC }_{i t} \\
& +\beta_{8} \text { DUALITY } Y_{i t}+\beta_{9} \text { BOARD }_{i t}+\beta_{10} A G E_{i t} \\
& +\beta_{11} \text { MANSHARE }_{i t}+\beta_{12} \text { STATE }_{i t} \\
& +\beta_{13} \text { HERFINDAHL } L_{i t}+\beta_{14} Q_{i t}+E_{i t}
\end{aligned}
$$

Studies on stock options in developed markets tend to use the calculated value of options based on the Black-Scholes formula as dependent variable (Yer- mack, 1995; Chen et al., 2013). Theoretically, our focus is on whether firms adopt stock options after the policy change in 2006; therefore, an indicator vari- able, ISSUE, is an appropriate dependent variable in our study. In line with our theoretical discussion, we use several explanatory variables shown in equa- tion (1) to discriminate between optimal contracting and managerial power. We measure state control with a dummy variable, STATE, which equals one if the firm is state controlled and zero otherwise. Ownership concentration is measured with the HERFINDAHL index based on the shareholding of the five largest shareholders. MANSHARE represents the percentage of shares owned by executives. AGE is the average age of all executives of each firm in each year. DUALITY is a dummy variable, which takes the value of one if the board chairman also takes the position of CEO or general manager and zero otherwise. BOARD is the number of board members indicating board size. COMC is a dummy variable, which takes the value of one if the firm has a compensation committee and zero otherwise.

$L E V$ measures financial leverage calculated as the ratio of total debt to total assets. We use two performance measurements, the accounting-based return on 
equity ( $R O E$ ) and the market-based annual stock return (RETURN). We also include the growth rate of total assets (GROWTH). SIZE refers to the natural logarithm of firms' total assets. Chen et al. (2010) and Conyon and He (2011) measure growth opportunity with the market-to-book ratio of equity. Instead, we use Tobin's $Q(Q)$, which is a better measure when comparing firms with different levels of debt. As outlined in the following section, Tobin's Q combines growth opportunities but also overvaluation, warranting a more comprehensiveanalysis.

We also control for industry effects. The industry classification is based on the 'Guidelines for the Industry Classification of Listed Companies (2012 Revision)' proposed by the CSRC, which has been used by the Shanghai and Shenzhen stock exchanges. The scientific research industry, the health industryand the IT industry are the top three industries with respect to the adoption rate of stock options, with a proportion of $11.84 \%, 10.53 \%$, and $6.13 \%$ respectively. To focus on these high-technology industries, we use the dummy HITECH. According to the 'National Hi-Tech Enterprises Management Approach', 5 the high-technology sector refers to information technology, biomedicine and new technologies (health), aerospace, new materials, hi-tech services, new energy and energy-saving technology, resource and environmental technology and tra- ditional industries transformed by high technology. In robustness checks, wealso incorporate the original 19 industry dummies in line with prior research. Alternately, we also specify random effects models. Table 1 presents the defini-tions of variables.

${ }^{5}$ Released by the Ministry of Science and Technology in 2008 


\subsection{Non-SOE subgroup analysis}

Since incentives for non-SOEs to adopt stock options could depend on the absence or presence of a controlling shareholder, we split non-SOEs into sub- groups. The Chinese Security Law and Company Law defines an investor as having control over a listed company based on the following criteria: (1) theinvestor holds more than $50 \%$ of the shares in the listed company; (2) the in-vestor controls over $30 \%$ of the share voting rights of the firm; (3) the investor controls the appointment of more than half of the members of the board of di-rectors through actual control of share voting rights; (4) the investor, by virtue of share voting rights held directly, exercises major influence over the resolutions of shareholders' general meetings of the company; or (5) other circumstances recognized by the CSRC. We therefore use two thresholds, 30\% and 50\%, todefine the presence of a principal shareholder. The dummies CONTROL 30 and CONTROL 50 are equal to one if the controlling shareholding exceeds the respective threshold, and zero otherwise.

\section{[Insert Table 1 here]}

\subsection{Decomposing valuation levels}

Valuation levels such as market-to-book ratios or Tobin's Q capture a firm's overvaluation but also growth expectations. Therefore, it is difficult to estab- lish whether a firm is actually overvalued or whether high valuation levels re-flect justifiable expectations about future growth. To determine firm (FIRM ), sector (SECTOR) and long-run overvaluation (LONGRUN), we modify the de-composition proposed by Rhodes-Kropf et al. (2005), which originally refers to decomposing market-to-book ratios. Following the same logic, we apply thedecomposition to Tobin's Q, i.e. our approach focuses on the entity level (e.g.total assets and market value of debt and equity) not the equity level (e.g. total 
equity and market value of equity). The first model (MODEL I) regresses thevalue of equity and debt (numerator of Tobin's Q), $m_{i t}$, of firm $i$ in year $t$ on the book value of total assets, $b_{i t}$ (denominator of Tobin's Q). The coefficients, $\alpha_{0 j t}$ and $\alpha_{1 j t}$, vary over time and industry $j$ based on a classification with 19industries.

$$
m_{i t}=\alpha_{0 j t}+\alpha_{1 j t} b_{i t}+E_{i t}
$$

Firm-specific overvaluation is equal to the observed market value of debt and equity minus the predicted value given a firm's fundamentals, where coefficients vary over time and across industries. Industry or sector related overvaluation refers to the difference in predicted valuations with varying timeindustry co-efficients and predictions based on time averages. Coefficients in (2) are aver-

g,ged over time so that $\alpha_{1 j}=\underline{1} \quad \alpha_{1 j t}$. The difference between predicted

$$
T \quad t=1
$$

valuation based on time averages and actual fundamentals determines the long- run component, which reflects a firm's long-run growth potential. In line withRhodes-Kropf et al. (2005), MODEL II extends (2) by including the naturallogarithm of the absolute value of earnings before interest and taxes, $e_{i t}$, and an interaction term between $e_{i t}$ and the indicator variable $I_{i t}$, which takes thevalue one if the firm makes losses and zero otherwise.

$$
m_{i t}=\alpha_{0 j t}+\alpha_{1 j t} b_{i t}+\beta_{0 j t} e_{i t}+\beta_{1 j t} I_{i t} e_{i t}+E_{i t}
$$

The decomposition mechanism is the same as in MODEL I, the difference is that (3) allows for additional fundamental variables. Finally, MODEL IIIincorporates financial leverage ( $L E V)$ as shown in (4).

$$
m_{i t}=\alpha_{0 j t}+\alpha_{1 j t} b_{i t}+\beta_{0 j t} e_{i t}+\beta_{1 j t} I_{i t} e_{i t}+\gamma_{j t} L E V_{i t}+E_{i t}
$$




\subsection{Propensity score matching for the post-event analysis}

Estimating the impact of stock options on various measures of firm per-formance such as profitability (ROE), growth (GROWTH) and stock returns (RETURN ) could be problematic due to an alleged self-selection bias. Because well-performing firms enjoy better market valuations, they are more likely to grant stock options. These firms are therefore more likely to present better post-event firm performance due to employee optimism (Bergman and Jenter, 2007). Consequently, an observed better performance in the post-event period may be just a continuation of superior past performance, i.e. positive autocor- relation, rather than a real improvement due to the issue of stock options.

Accordingly, we use propensity score matching to form a treatment group and a control group. In order to find the most appropriate matching obser-vations for the treatment group, we first specify a logistic regression model to identify factors that predict a firm's decision to award stock options. Hence, we first ask the question: why do companies issue stock options? In line with ourtheoretical framework, this decision is likely to be influenced by firm-specific fac-tors, market factors, overvaluation, industry factors, and corporate governance mechanisms including CEOs' power. Second, we determine propensity scores based on an optimal selection model in terms of information criteria following a general-tospecific approach. Based on the nearest neighborhood matchingmethod, we form a matched control group. Companies in the control grouphad the highest probability of adopting options, i.e. they are a close match to the treatment group in terms of underlying factors - but they did not issue op- tions. The treatment group refers to companies that adopted stock options. Bycomparing the treatment group, the matched and unmatched control group we can establish whether stock options actually enhanced value drivers (GROWTH, ROE ) and led to higher shareholder value (RETURN ). This post-eventanalysis 
offers an opportunity to assess whether stock options work as promised by the optimal contracting approach, or only work in favor of managers in line with the managerial power approach.

\section{Empirical analysis}

\subsection{Descriptive statistics}

Table 2 presents annual figures including the number of new stock option plans issued (ISSUE), the number of existing plans (OPTION) and the numberof established stock option plans in SOEs and high-tech companies. Since theirfirst adoption in 2006, between $0.8 \%$ and $3.6 \%$ of all companies in the sample have issued new stock options in a respective year. In 2007, only 13 options were granted, which can be explained by the onset of the Global Financial Cri-sis that affected financial markets severely. At a first glance, Table 2 seems to indicate that 10 years since China first introduced equity compensation in 2006, only a few firms have adopted stock options as part of their executive paypackages. However, considering the number of firms with outstanding stock op-tions, it becomes apparent that $15.5 \%$ of companies use equity compensations in2014. Moreover, there is a profound difference between state-owned enterprises (SOEs), where equity compensation is rare with only $7.9 \%$ of SOEs awarding stock options, and companies in the high-technology sector, where $30.5 \%$ rely on stock options. These descriptive patterns suggest that state ownership (STATE ) and operating in the high-technology sector (HITECH) are likely contenders toexplain the adoption of equity compensation.

\section{[Insert Table 2 here]}

To capture the alleged impact of controlling shareholders, Table 3 displays the proportion of stock options in subgroups of non-SOEs applying the two 
thresholds $30 \%$ and $50 \%$, respectively. Interestingly, the prevalence of stock options between firms with and without controlling shareholder is quite close based on the $30 \%$ threshold. However, considering the $50 \%$ threshold controlled firms exhibit markedly lower adoption rates.

\section{[Insert Table 3 here]}

To reveal the underlying motive for adopting stock options in controlled firms, we investigate the level of tunneling of non-SOE subgroups around is- sues. Since inter-corporate loans tend to be the main channel through which controlling shareholders expropriate assets (Jiang et al., 2010), we use other re- ceivables to total assets (ORECTA) to proxy tunneling in line with prior studies (Liu and Tian, 2012; Wang and Xiao, 2011). Table 4 displays the level of inter-corporate loans (ORECTA) for subgroups one year before [t-1], one year after [t+1] and two years after $[t+2]$ firms issued stock options. As tunneling alsodepends on other firm and industry-specific factors, we fit a panel OLS model controlling for firm size, leverage, growth, profitability and industry. Table 4 reports differences in tunneling accounting for these firm and industry-specific effects. Tunneling has increased only in the case of controlled firms based on the $50 \%$ threshold after the introduction of stock options. Therefore, the increase ininter-corporate loans in the post-option period compared to the pre-option pe-riod demonstrates that stock options could be another tool used by controllingshareholders to increase tunneling.

\section{[Insert Table 4 here]}

Table 5 summarizes descriptive statistics of all firm-level variables used in our empirical analysis. All variables have been winsorized at the 5 and 95-percentile to mitigate the impact of outliers. In line with our theoretical considerations, we use a set of firm controls including firm size (SIZE), financial leverage ( $L E V)$, 
annual growth rates in total assets (GROWTH ) and return on equity ( $R O E$ ). The latter two variables are also outcome variables in our assessment of the im- pact of stock options on firms' value drivers. Due to using the natural logarithm of total assets as a measure of firm size, the resulting distribution is symmet- ric. On average, companies have grown by $15 \%$ a year, and return on equity has been $7 \%$, underlining high growth but only modest levels of profitability. All firm controls exhibit a considerable range, highlighting heterogeneity in the sample. Stock returns (RETURN ) have varied widely in the sample. Market valuation measured by Tobin's Q (Q) might explain the timing of awarding stock options. To identify firm (FIRM), industry (SECTOR) and long-term (LON-GRUN) overvaluation, we conducted a decomposition as discussed in Section

4.4. As shown in Table 2 state-ownership (STATE) and operating in the high- technology sector matter (HITECH ). On average, only 7\% of companies are in the high-technology sector, whereas 31\% are controlled by the state. Finally, Table 5 includes proxies of corporate governance. On average $20 \%$ of companies exhibit DUALITY as CEOs also serve as chairmen of the board of directors. On average 32\% of companies have committees to assess executives' compen- sations COMC. The size of the board of directors varies considerable with a maximum number of 22 members. The age of executives ( $A G E$ ) is rather con- centrated around 48 years, which is young compared to more developed markets. Shareholding of executives is on average 7\% (MANSHARE).

Ownership concentration measured by the HERFINDAHL index is relatively high in China. Furthermore, the presence of controlling shareholder is still common. On average $25 \%$ of listed firms are controlled by a shareholder who owns over half of the outstanding shares (CONTROL5O). When we define a controlling shareholder as holding over $30 \%$ of shares, the percent of firms with a controlling shareholder increases to $62 \%$ (CONTROL30). The average extent of 
tunneling measured by inter-corporate loans (ORECTA) in our sample reaches $3 \%$. It is remarkably lower than the average of $8.1 \%$ for the period from 1996 to 2004 reported by Jiang et al. (2010) and slightly lower than the average of 3.5\% reported by Liu and Tian (2012) for the period from 2004 to 2010. These discrepancies reflect differences in sampling and most importantly a reduction of the measure over time.

\section{[Insert Table 5 here]}

Table 6 shows the contractual features of newly issued stock options. Panel A focuses on all newly issued stock option plans. Panel B reports the charac- teristics of stock options in the case of state-owned enterprises, whereas Panel C refers to companies operating in the hightechnology sector. The stock op- tion plans in China only cover an average of $3.31 \%$ of the outstanding shares (SHARE), which is relatively low compared to US firms. ${ }^{6}$ Accordingly, dis- tinguishing between small and large awards defined as options covering less or more than $5 \%$ of the firm's total outstanding shares as suggested by Kim and Ouimet (2014), is less meaningful in the Chinese context. Additionally, stock options only cover an average of $0.09 \%$ employees within firms (EMP), only a small proportion of the total number of employees. By contrast, in US firms, stock options or other profit sharing plans usually covers over half of the total number of employees (Kim and Ouimet, 2014). Another peculiarity of Chinese stock option plans is that on average only 24\% are awarded to executives (EXE), whereas 68\% are allocated to so-called 'technicians' (TEC). These 'technicians' include the heads of IT departments and finance department with functional ex- pertise required for the success of companies. Drawing the line between essential 'technicians' and executives seems to be difficult based on public information.

\footnotetext{
${ }^{6}$ For instance, Core and Guay (2001) report that during the period 1994 to 1997, stock options in US firms covered on average $6.9 \%$ of the total number of shares outstanding.
} 
According to Table 6 , at least $75 \%$ of the stock options have vesting periods of at least four years as the 25-percentile is four years (VEST). On average, thevesting period is 4.92 years, and the median is five years. Only a small fraction of stock option plans exhibit vesting periods in excess of five years. The maximumobserved value is ten years, which is more in line with US stock options, where vesting periods tend to be ten years or more. Regarding the awarding method, on average $60 \%$ of stock options are awarded through multiple issues (MULT) compared to $40 \%$ of one-off awards. These figures might simply reflect the fact that stock options have not been introduced before 2006. Panel B of Table 6 highlights that stock options issued by SOEs exhibit higher vesting periods with an average of 6.25 years and they tend to be one-offs as only $17 \%$ are multiple issues. Interestingly, stock options cover less employees and tend to go to executives. Finally, Panel $\mathrm{C}$ shows a sharp contrast as vesting periods are short with an average of 4.73 years, most options refer to multiple issues and equity compensations target mostly 'technicians', which stresses their value for high-technology companies in a competitive market for talent.

\section{[Insert Table 6 here]}

\subsection{The determinants of stock option plans}

This section explores the determinants of Chinese stock option plans. Due to a policy change in 2006, companies were permitted to issue stock options, and one year later the first option plans emerged. Arguably, between the decision to issue a stock option and the actual issue, there is a considerable time gap, which should ensure that explanatory variables are weakly exogenous in the sense that they are known, i.e. predetermined, at the time the decision is made. Prior literature such as Chen et al. (2010) lagged all explanatory variables by one year to ensure weak exogeneity. By default, this approach reduces the 
sample size considerably. In robustness check, we adopt this method, leading to consistent results. However, the issue with using lagged variables is that many observations are lost, most crucially observations in the years 2004 and 2005 prior to the policy change.

Table 7 shows the results of logistic regressions with the initial issue of stock options as dependent variable. Model [A] focuses on firm-specific control vari- ables including firm size (SIZE), financial leverage ( $L E V)$, annual growth in total assets (GROWTH ) and return on equity (ROE ). Model [B] considers an- nual stock returns prior to the issue (RETURN) and Tobin's $\mathrm{Q}(\mathrm{Q})$. Model [C] decomposes Tobin's $\mathrm{Q}$ into firm (FIRM ), industry (SECTOR) and long- run (LONGRUN) overvaluation. Model [D] explores the impact of operating in the high-technology sector (HITECH) and state-ownership (STATE). Model[E] considers governance mechanisms including DUALITY, the existence of re- muneration committees (COMC), the number of board members (BOARD), average age of executives ( $A G E$ ), stock ownership of executives (MANSHARE) and a measure of ownership concentration (HERFINDAHL). All specifications in Table 7 use robust standard errors to account for heteroskedasticity.

Table 7 shows that the majority of the variables are significant, apart from firm size (SIZE), the number of board members (BOARD) and ownership con- centration (HERFINDAHL). The following variables test the optimal contract- ing approach based on agency theory. First, executives' direct shareholding (MANSHARE) has a positive impact on granting stock options, indicating that managers with higher equity stakes in the companies they run are more likely to be awarded with stock options. This finding is contrary to the optimal contract- ing approach but consistent with the managerial power approach. Executives with high shareholding should have interests aligned with shareholders as they participate in any increase in shareholder value. Accordingly, additional incen- 
tives through stock options seems to be obsolete, constituting another form of benefiting from future value creation.

Second, consistent with Conyon and He (2012) and Fang et al. (2015), we also find that state control (STATE) has a negative impact on issuing stock op- tions, in line with agency theory. SOEs are controlled through various channels, increasing monitoring and limiting information asymmetry. Moreover, the state has different interests compared to other private shareholders, not restricted to maximizing shareholder value. Hence, it is conceivable that additional in- centives such as stock options are less important. Finally, consistent with our prediction, the result on executives' age shows that young executives are more likely to be awarded with options as incentives, which maximizes their impact given the longer time span of active work.

However, we did not observe a significant partial impact of ownership concen- tration (HERFINDAHL). This contradicts the results of Conyon and He (2012) and Fang et al. (2015), who found negative coefficients albeit of small magnitude $(\beta=-0.01, p<0.05 ; \beta=-0.0385, p<0.01$, respectively). Their measures of ownership concentration, though, are different from ours in that they use the equity ownership of the largest shareholder or the two largest shareholders re-spectively, while we construct a wider Herfindahl index based on the five largestshareholders. In addition, Conyon and He (2012) also consider restricted stockand appreciation rights in their analysis, while we focus on stock options. Com-panies operating in the high-technology sector (HITECH) have a tendency to use stock options, which is in line with our descriptive findings and consistent with agency theory in that these firms need to rely more on $R \& D$ resulting inhigher degrees of information asymmetry. This finding is in line with Core et al. (2003).

In a sense, model [A] in Table 7 highlights that companies in a strong posi- 
tion, both in terms of value drivers and financial health, are more likely to issuestock options. These companies excel regarding growth rates (GROWTH ), prof-itability (ROE) and low leverage ( $L E V)$. Our finding on leverage is in line with Fang et al. (2015), and the positive effect of profitability confirms Fang et al. (2015). As shown in [B] a high Tobin's Q $(Q)$ tend to increase the likelihood that companies issue stock options. So one wonders why apparently success- ful companies need stock options to ensure that executives focus on enhancingshareholder value. Is it possible that powerful CEOs try to get access to stock options to benefit from an already successful company? Model [B] provides an- other clue regarding the timing of issuing options in that negative annual stockreturns (RETURN ) make issues more likely. Of course, high valuation levels measured by Tobin's Q can be due to high growth expectations, which might warrant options to ensure that managers work hard to fulfill these long-term expectations. Yet, Tobin's Q also reflects overvaluation of firms and industries. Using the decomposition method discussed in Section 4.4, we are able to identifythe underlying source of high Tobin's Qs, which we call firmspecific (FIRM ), sector-specific (SECTOR) and long-run (LONGRUN ) component. Model [C] demonstrates that overvalued firms and industries have a more pronounced par-tial impact on the timing of stock options than long-term growth expectations. Higher growth opportunities matter, confirming Chen et al. (2010), Conyon and He (2012) and Fang et al. (2015); however, overvaluation seems to be the pre-dominant factor. One possible interpretation is that managers in well performed firms receive stock option as a kind of rent-extracting method because better past performance could also lead to better future performance even when the executives do not work that hard. In summary, there is only partial support forthe optimal contracting approach.

Considering our proxies for testing the managerial power approach, most 
findings show a positive and significant partial impact. In particular, manage- rial direct shareholdings (MANSHARE), duality (DUALITY) and establishing compensation committees (COMC) have a positive impact on issuing stock op- tions. These significant partial impacts demonstrate that when senior managers own more stocks in firms, when CEOs simultaneously serve as board chairman and when the firm has compensation committee, stock options are more likely to be granted. In line with our theoretical discussion, managers are considered to be more powerful if they have ownership rights, have influence over the board and promote the introduction of compensation committees. Put differently, our estimates show that companies are more likely to adopt options when executives have more power within organizations. These findings are consistent with Chen et al. (2010) and Chen et al. (2011); however, they are not aligned with Fang et al. (2015). In summary, our findings largely accord with predictions derived from the the managerial power approach.

\section{[Insert Table 7 here]}

To derive an optimal model specification in the sense of minimizing informa- tion criteria such as the Akaike criterion, Table 8 starts with a general model $[\mathrm{F}]$ combing all specification shown in Table 7. Using a general-to-specific ap- proach, we remove insignificant explanatory variables from Model [F] and finda reduced specification [G]. Likelihood ratio tests confirm that eliminating the variables BOARD, LONGRUN, RETURN and HERFINDAHL does not lead to a worse model. The likelihood ratio reaches 6.50 with a p-value of 0.165 ; hence, we cannot reject the null hypothesis that the coefficients of the four eliminatedvariables are equal to zero. To check for multicollinearity, we determine varianceinflation factors (VIF) for all explanatory variables. The maximum VIF is 5.47in the case of firm size, which is still far below the critical level of 10. As we decompose Tobin's $Q$ into its three components, Tobin's $Q$ is not included in 
any specification to avoid multicollinearity.

Model [H] uses the reduced set of explanatory variable based on [G], however, applying the model to the full sample with robust standard errors. Specification [I] removes the dummy for the high-technology sector, HITECH, and insteadincludes industry dummies. In addition to [I], model [J] also considers year dummies. Finally, model $[\mathrm{K}]$ refers to a random effects specification. Essentially, our main empirical findings do not change depending on the model specification or method used, highlighting a high degree of robustness.

\section{[Insert Table 8 here]}

Since non-SOEs also exhibit differences in their motivation to issue stock options due to the presence or absence of controlling shareholders, we split non- SOEs into subgroups to investigate the alleged differences. The previous general model [F], excluding state control (STATE), is fitted to all four subgroups based on the two thresholds regarding stock ownership. Model [F1] and [F3] are based on sub-samples with controlling shareholder and [F2] and [F4] are firms with- out. Table 9 shows that regardless of the presence of a controlling shareholder, higher managerial shareholding (MANSHARE) and younger executives (AGE) consistently contribute to a higher propensity of awarding stock options. Firm performance (ROE) and DUALITY also show significantly positive partial im- pact on awarding options in three out of four models except for [F3].

Furthermore, results of [F2] and [F4] highlight that when a controlling share- holder is absent, firm-specific variables tend to play a more important role in shaping equity compensation. By contrast, firms with a controlling shareholder seem less likely to take these factors into account as shown in [F1] and [F3]. It seems that most predictions based on the managerial power perspective hold in all subgroups - apart from DUALITY in firms controlled by a shareholder holding more than $50 \%$. 
It seems that most predictions based on the managerial power perspective hold in all subgroups. It is apparent that managers can pursue private benefits through taking advantage of their power within firms not controlled by a princi- pal shareholder. Why would companies with a controlling shareholder still need stock options given the power to monitor managers?

A possible explanation supported by Table 4 is that, the controlling share- holder either awards stock options to induce the mangers to collude in tunneling or pursue the dividend from stock options themselves through their control of managerial positions. Several previous studies also demonstrate the prevalence of tunneling in Chinese listed firms through various channels (Gao and Kling, 2008; Jiang et al., 2010; Liu and Tian, 2012; Wang and Xiao, 2011).

\section{[Insert Table 9 here]}

\subsection{The impact of stock option plans on firm performance}

After revealing the underlying determinants of stock option plans, we in- vestigate whether stock options had a positive impact on various measures of firm performance, including profitability ( $R O E$ ), firm growth (GROWTH), and stock returns (RETURN). Comparing these performance measures directly be- tween firms that adopted stock option and those that did not is likely to lead to biased results due to an alleged selfselected problem. That is to say, firms with better prior firm performance are more likely than other firms to adopt stock options, as shown in Table 7 and 8. Hence, their superior post-event firm performance compared to firms that did not issue stock options might be due to past performance, unrelated to incentives provided through stock options.

To account for the alleged self-selected problem, we use a propensity score matching approach proposed by Rosenbaum and Rubin (1983) to form a treat- ment group and a control group based on the potential determinants of stock 
options uncovered in able 7 and 8 . The treatment group refers to firms that adopted stock options during our sample period. The control group comprises those firms that share similar characteristics compared to the treatment group but did not adopt stock options. To illustrate the idea, we know that large firms with low leverage, high growth and high profitability among other characteris- tics are more likely to issue stock options. So by self-selection, the treatment group consists of firms that share these characteristics. The propensity score matching approach identifies firms that exhibit similar characteristics, e.g. large firms with low debt, high growth and profitability, that did not use stock op- tions. The outcome after the event (i.e. issue of options) in terms of the three performance measures is then compared between the treatment group and the control group. Hence, any differences detected cannot be due to the matched characteristics but must be caused by stock options.

In particular, we use a 5-nearest neighbors matching approach to select for each observation in the treatment group five similar observations in the con- trol group. This method ensures that all firms, treated or untreated, share similar firm characteristics. The first step of propensity score matching is to calculate the propensity score of the observations which indicate firms' likeli- hood of adopting stock options in a particular year. To avoid missing data for all firm characteristics, there are 396 observations out of 410 in the treatment group. Secondly, we use 5-nearest neighbors matching method to form a match- ing group which have the closest propensity scores to those in the treatment group. Hence, 1661 observations are selected as matched controls. Table 10 reports descriptive statistics for the treated, matched and unmatched sample.

\section{[Insert Table 10 here]}

Panel A and B of Table 10 show that all firm characteristics, identified as drivers of issuing stock options, are very similar in the treatment and control 
group by construction. Thus indicates a high degree of successful matching achieved by the 5-nearest neighbors matching method. In contrast, Panel C of Table 10 clearly indicates considerable differences between firms withstock options and their matched counterparts as compared to the unmatched sample. To investigate the impact of stock options, we aim to identify whether the use of them improved firm performance measured by profitability ( $R O E)$, firm growth (GROWTH), and stock returns (RETURN). We use the average treat- ment effect on the treated (ATT) to estimates the potential difference between the treatment group and the matched control group. Table 11 reports our findings for the three measures of firm performance. Standard errors reported are bootstrapped. In particular, we explore performance measures one year after stock options were issued to ensure weak exogeneity, i.e. stock options are issued before performance is measured. Table 11 highlights that regardless which performance measure we use, there is no significant difference between the treatment group and the matched control group (see rows indicated by ATT). In contrast, without the application of the propensity score matching approach, i.e. considering the unmatched sample (see rows indicated by Un- matched), firms that adopted stock options seem to exhibit higher profitability (ROE) and growth (GROWTH) after the issue. Interestingly, considering stock market performance (RETURN) even the unmatched sample reveals that firms with stock options underperformed after the issue. In summary, we do not find any evidence that stock options improved firm performance or firm value.

\section{[Insert Table 11 here]}

\section{Conclusion}

It has been a decade since China first permitted equity compensations in 2006. This study presents the most recent picture of 
and it is the first attempt to analyze executive compensation from both per- spectives, optimal contracting and managerial power. Our results indicate that stock options cannot be merely explained by the traditional optimal contracting approach. Managerial power plays an important even a predominant - role in firms' decisions to grant stock options. Under the managerial power approach, managers have both the incentive and ability to expropriate shareholders by adopting more favorable executive compensation. Stock options can be a favor- able compensation as they do not totally reflect managers' own performance. Therefore, if managerial power is relevant in the Chinese context, we would ob- serve a positive correlation between managerial power and the adoption of stock options. Our results support this prediction.

Since managerial power is latent, we use managerial stock shareholding, the existence of compensation committee, duality and board size as proxies. We con- sider managers powerful if they hold more shares, if there exists a compensation committee, if CEOs also serve as board chairman and if there are more mem- bers on boards. First, we find that when managers own more equity, they are more likely to be awarded with stock options. As higher managerial sharehold- ing is usually accompanied with more power within the organizations, we thus conclude that higher managerial stock ownership gives managers more power to adopt favorable pay, such as stock options. This contradicts the traditional op- timal contracting approach which argues that stock options would be less likely to be adopted in firms with higher managerial shareholding, because managerial shareholding would largely reduce agency problem by providing managers the most direct incentives.

Our result on compensation committees and duality also support the man- agerial power approach. We find that if firms have compensation committees, managers are more likely to be awarded with options. It is possible that be- 
cause the compensation committee members are hired by human resources and are indirectly subordinate to managers, their gratitude towards managers leads them to set favorable compensation packages in the interest of managers, even though the committee is originally designed to offer cost effective pay arrange- ment. Favorable pay can also be achieved through managers exerting potential influence over compensation committees. We also find that when CEOs also serve as board chairman, managers are more likely to be granted options. This result suggests that managerial power due to duality provides self-dealing op- portunities to extract rents.

Except for managerial power, ownership type, firms' and executives' char- acteristics are also essential factors in granting stock options in Chinese firms. Our results demonstrate that state controlled firms are less likely to adopt stock options than private firms. In non-SOEs, however, motives for adopting stock options differ. In particular, if controlling shareholders are present, stock op- tions are less common - but if they are used they seem to be awarded to induce managers to collude with controlling shareholders, leading to tunneling. Alter- natively, the controlling shareholder could also pursue the 'windfall' from stock options through their own control over managerial positions.

However, ownership concentration does not matter. Firms with younger ex- ecutives are more willing to grant stock options as compensation. In addition, larger firms and firms with lower financial leverage and more growth opportu- nities are more likely to adopt stock options. As to prior firm performance, we observe a significant relationship between prior ROE and options. Finally, in line with Core et al. (2003), our results indicate that high technology firms are more likely to award stock options.

We then investigate whether stock options have improved firm performance. In contrast to prior literature (Chen et al., 2010), we use a propensity score 
matching method to remove an alleged self-selection bias. We use both ac- counting based ROE and stock based annual stock return to measure firm per- formance. In addition, we consider firm growth. Our results show that the Chinese stock options did not improve profitability, growth and annual stock returns. This contradicts Fang et al. (2015), who reports a positive impact of stock options on firm performance. The latter is most likely due to self-selection, not controlled for by Fang et al. (2015).

In summary, Chinese stock options have not achieved expected results in terms of improving firm performance. Although they are originally designed to benefit shareholders, managerial power and rent exaction also play significant roles. Stock options seem to be a game between powerful managers and cor- porate governance mechanisms. To what extent will managerial influence move the pay arrangement away from the optimal contracting outcome depends on how the Chinese firms balance the increasing managerial power with responding managerial accountability. This is especially the case in China where managers have been achieving considerable control over the firms due to continuous re- forms. Less developed financial disclosure also contributes to the rent exaction of managers. In addition, tunneling is still evident in Chinese firms, though in a more subtle form. By awarding equity compensations to managers, control- ling shareholders pave their way to take advantage of minority shareholders. In summary, current legal protections and regulations in Chinese stock markets are not fully developed to mitigate the entrenchment from both managers and controlling shareholders effectively. Although a serious of regulations and prac- tices had been brought forward to complete the Chinese capital market, their real impacts are still in doubt. 


\section{References}

Bebchuk, L. A., Fried, J. M., 2003. Executive compensation as an agency prob- lem. Tech. rep., National Bureau of Economic Research.

Bergman, N. K., Jenter, D., 2007. Employee sentiment and stock option com-pensation. Journal of Financial Economics 84 (3), 667-712.

Berle, A. A., Means, G. G. C., 1991. The modern corporation and private property. Transaction publishers.

Cao, J., Pan, X., Tian, G., 2011. Disproportional ownership structure and pay-performance relationship: evidence from china's listed firms. Journal of Cor- porate Finance 17 (3), 541-554.

Chen, J., Ezzamel, M., Cai, Z., 2011. Managerial power theory, tournament theory, and executive pay in china. Journal of Corporate Finance 17 (4), 1176-1199.

Chen, J. J., 2005. Corporatisation of china's state-owned enterprises and corporate governance'. Challenges for China's development: An enterprise per- spective 4, 58.

Chen, J. J., Liu, X., Li, W., 2010. The effect of insider control and global benchmarks on chinese executive compensation. Corporate Governance: An International Review 18 (2), 107-123.

Chen, Z., Guan, Y., Ke, B., 2013. Are stock option grants to directors of state- controlled chinese firms listed in hong kong genuine compensation? The Ac- counting Review 88 (5), 1547-1574.

Claessens, S., Djankov, S., Fan, J. P., Lang, L. H., 2002. Disentangling the in- centive and entrenchment effects of large shareholdings. The journal of finance 57 (6), 2741-2771.

Conyon, M. J., He, L., 2011. Executive compensation and corporate governance in china. Journal of Corporate Finance 17 (4), 1158-1175.

Conyon, M. J., He, L., 2012. Ceo compensation and corporate governance in china. Corporate Governance: An International Review 20 (6), 575592.

Core, J., Guay, W., 1999. The use of equity grants to manage optimal equity incentive levels. Journal of Accounting and Economics 28 (2), 151184.

Core, J. E., Guay, W. R., 2001. Stock option plans for non-executive employees.Journal of Financial Economics 61 (2), 253-287.

Core, J. E., Guay, W. R., Larcker, D. F., 2003. Executive equity compensation and incentives: A survey. Economic Policy Review 9 (1).

Fama, E. F., Jensen, M. C., 1983. Separation of ownership and control. TheJournal of Law \& Economics 26 (2), 301-325.

Fang, H., Nofsinger, J. R., Quan, J., 2015. The effects of employee stock op- tion plans on operating performance in chinese firms. Journal of Banking \& Finance 54, 141-159. 
Firth, M., Fung, P. M., Rui, O. M., 2006. Corporate performance and ceo compensation in china. Journal of Corporate Finance 12 (4), 693-714.

Gao, L., Kling, G., 2006. Regulatory changes and market liquidity in chinese stock markets. Emerging Markets Review 7 (2), 162-175.

Gao, L., Kling, G., 2008. Corporate governance and tunneling: Empirical evi-dence from china. Pacific-Basin Finance Journal 16 (5), 591-605.

Gao, L., Kling, G., 2012. The impact of corporate governance and external audit on compliance to mandatory disclosure requirements in china. Journal of International Accounting, Auditing and Taxation 21 (1), 17-31.

Gillan, S. L., 2001. Has pay for performance gone awry? views from a corporate governance forum. dialogue.

Grossman, S. J., Hart, O. D., 1988. One share-one vote and the market forcorporate control. Journal of Financial Economics 20, 175-202.

Groves, T., Hong, Y., McMillan, J., Naughton, B., 1994. Autonomy and in- centives in chinese state enterprises. The Quarterly Journal of Economics, 183-209.

He, Q., 1998. The trap of modernization. Beijing:Contemporary China Press (in Chinese).

Jensen, M. C., Meckling, W. H., 1976. Theory of the firm: Managerial behavior, agency costs and ownership structure. Journal of Financial Economics 3 (4), 305-360.

Jensen, M. C., Murphy, K. J., 1990. Performance pay and topmanagement incentives. Journal of Political Economy, 225-264.

Jiang, G., Lee, C. M., Yue, H., 2010. Tunneling through intercorporate loans: The china experience. Journal of Financial Economics 98 (1), 1-20.

Johnson, S., Porta, R. L., de Silanes, F. L., Shleifer, A., 2000. Tunneling. TheAmerican Economic Review 90 (2), 22-27.

URL http://www.jstor.org/stable/117185

Kim, E., Ouimet, P., 2014. Broad-based employee stock ownership: Motivesand outcomes. The Journal of Finance 69 (3), 1273-1319.

Kling, G., Gao, L., 2005. Calendar effects in chinese stock market. Annals of Economics and Finance 6 (1), 75-88.

Kling, G., Gao, L., 2008. Chinese institutional investors' sentiment. Journal of International Financial Markets, Institutions and Money 18 (4), 374387.

Liu, Q., 2006. Corporate governance in china: Current practices, economic ef-fects and institutional determinants. CESifo Economic Studies 52 (2), 415- 453 .

Liu, Q., Tian, G., 2012. Controlling shareholder, expropriations and firm's lever-age decision: Evidence from chinese non-tradable share reform. Journal of Corporate finance 18 (4), 782-803.

Murphy, K. J., 1999. Executive compensation. Handbook of Labor

Economics 
3, 2485-2563.

Rhodes-Kropf, M., Robinson, D., Viswanathan, S., 2005. Valuation waves and merger activity: The empirical evidence. Journal of Financial Economics 77, 561-603.

Rosenbaum, P. R., Rubin, D. B., 1983. The central role of the propensity scorein observational studies for causal effects. Biometrika 70 (1), 41-55.

Shleifer, A., Vishny, R. W., 1997. A survey of corporate governance. The Journalof Finance 52 (2), 737-783.

Sun, Q., Tong, W. H., 2003. China share issue privatization: the extent of its success. Journal of Financial Economics 70 (2), 183-222.

Wang, K., Xiao, X., 2011. Controlling shareholders' tunneling and executive compensation: Evidence from china. Journal of Accounting and Public Policy 30 (1), 89-100.

Yermack, D., 1995. Do corporations award ceo stock options effectively. Journalof Financial Economics 39 (2), 237-269.

Yermack, D., 1996. Higher market valuation of companies with a small boardof directors. Journal of Financial Economics 40 (2), 185-211. 
Table 1: Variables and definitions

\begin{tabular}{|c|c|}
\hline Variables & Definition \\
\hline ISSUE & Dummy if company issues stock options in year $t$ \\
\hline OPTION & Dummy if company has issued stock options \\
\hline HITECH & Dummy if company belongs to the high-tech \\
\hline industry LEV & Long and short-term debt to total assets \\
\hline SIZE & Natural log of total asset \\
\hline GROWTH & Annual growth rate of total \\
\hline assets ROE & Return on equity \\
\hline RETURN & Annual stock return \\
\hline COMC & Dummy if the firm set compensation \\
\hline \multicolumn{2}{|c|}{$\begin{array}{l}\text { committee DUALITY Dummy if the CEO serves also as } \\
\text { the chairman }\end{array}$} \\
\hline & of the board \\
\hline BOARD & The number of directors on the board \\
\hline AGE & Average age of executives \\
\hline $\begin{array}{l}\text { MANSHARE } \\
\text { total }\end{array}$ & Shareholding of executives in \% of \\
\hline \multicolumn{2}{|c|}{$\begin{array}{l}\text { STATE Dummy if the state is the dominant } \\
\text { shareholder HERFINDAHLIndex based on the five largest } \\
\text { shareholders }\end{array}$} \\
\hline CONTROL30 & Dummy if controlling shareholder holds more than $30 \%$ of \\
\hline share CONTROL & 50 Dummy if controlling shareholder holds more than \\
\hline $50 \%$ of shares Q & $\begin{array}{l}\text { Tobin's Q defined as market value of equity and debt } \\
\text { relative to totalassets }\end{array}$ \\
\hline FIRM & Firm-specific overvaluation based on a decomposition \\
\hline SECTOR & Industry-specific overvaluation based on a \\
\hline $\begin{array}{l}\text { decomposition } \mathrm{L} \\
\text { decomposition }\end{array}$ & ONGRUN Long-term growth expectations based on a \\
\hline ORECTA & Proxy for tunneling measured by other receivables to total asset \\
\hline
\end{tabular}


Table 2: The adoption of stock options

The table reports the number of newly awarded stock option plans per year in column ISSUE and in \% of all companies in the sample in the column labeled in \% of total. The column OPTION shows the number of firms with an active stock option plan, and the fifth column expresses this number in \% of all companies. The last two columns report the proportion in

$\%$ of state-owned companies (STATE) that have an option plan and the proportion in \% of companies in the high technology sector $(H I T E C H)$ that have adopted stock options.

\begin{tabular}{lllllll}
\hline Year & ISSUE & $\begin{array}{l}\text { in } \% \\
\text { of }\end{array}$ & OPTION & $\begin{array}{l}\text { in } \% \\
\text { of }\end{array}$ & $\begin{array}{l}\text { in } \% \\
\text { of STATE }\end{array}$ & $\begin{array}{l}\text { in } \% \\
\text { of HITECH }\end{array}$ \\
\hline 2004 & 0 & 0.00 & 0 & 0.00 & 0.00 & 0.00 \\
2005 & 0 & 0.00 & 0 & 0.00 & 0.00 & 0.00 \\
2006 & 32 & 2.20 & 32 & 2.20 & 0.81 & 3.30 \\
2007 & 13 & 0.83 & 45 & 2.86 & 1.35 & 4.12 \\
2008 & 56 & 3.45 & 100 & 6.15 & 3.09 & 11.65 \\
2009 & 18 & 1.02 & 112 & 6.32 & 3.11 & 11.11 \\
2010 & 59 & 2.77 & 159 & 7.47 & 3.95 & 15.34 \\
2011 & 86 & 3.64 & 237 & 10.03 & 4.56 & 21.86 \\
2012 & 69 & 2.77 & 292 & 11.72 & 6.25 & 25.00 \\
2013 & 87 & 3.43 & 364 & 14.35 & 6.73 & 28.72 \\
2014 & 62 & 2.34 & 410 & 15.46 & 7.87 & 30.50 \\
\hline
\end{tabular}


This is the accepted version of an article published by Elsevier in Pacific-Basin Finance Journal Vol. 46 Part A., 124140. Published version available from: https://doi.org/10.1016/j.pacfin.2017.09.007

Accepted version downloaded from SOAS Research Online: http://eprints.soas.ac.uk/24654/ under CC-BY-NC-ND 4.0 International Licence

Table 3: The adoption of stock options in non-SOEs with and without controlling shareholder

The table reports mean adoption rates of stock option plans in non-SOEs with and with- out controlling shareholder, applying the thresholds $30 \%$ and $50 \%$ respectively. The columns Control refer to non-SOEs with controlling shareholder, whereas the columns No control refer to those without controlling shareholder.

\begin{tabular}{ccccc}
\hline & \multicolumn{2}{c}{$30 \%$} & \multicolumn{2}{c}{$50 \%$} \\
Year & Contro & No control & $\begin{array}{l}\text { Contro } \\
\text { l }\end{array}$ & No control \\
\hline 2004 & 0.00 & 0.00 & 0.00 & 0.00 \\
2005 & 0.00 & 0.00 & 0.00 & 0.00 \\
2006 & 4.44 & 4.05 & 1.54 & 4.54 \\
2007 & 5.13 & 4.61 & 4.60 & 4.88 \\
2008 & 8.24 & 11.17 & 8.70 & 9.89 \\
2009 & 5.67 & 10.41 & 6.14 & 8.12 \\
2010 & 7.04 & 10.56 & 7.32 & 8.73 \\
2011 & 9.54 & 13.50 & 8.64 & 11.75 \\
2012 & 11.32 & 14.72 & 9.90 & 13.41 \\
2013 & 14.64 & 16.71 & 11.96 & 16.46 \\
2014 & 15.81 & 17.47 & 12.01 & 17.61 \\
\hline
\end{tabular}


Table 4: Tunneling in non-SOEs subgroups before and after issuing stock options

The table reports a proxy for tunneling around stock option issues in non-SOEs with and without controlling shareholder. We use inter-corporate loans, measured by other receivables to total assets, to proxy the level of tunneling. [t-1] denotes one year before the firm issued stock options, [t+1] and [t+2] denote one year and two years after the issue, respectively. The first two columns show the difference in expected tunneling comparing [t-1] and $[t+1]$, and p-values refer to t-tests. The third and fourth column compares expected tunneling be- fore and two years after the adoption of stock options. We fit a panel OLS model to control for firm size, leverage, growth, profitability and industry. Hence, reported differences in tun- neling account for these firm and industryspecific effects.

\begin{tabular}{lcccc}
\hline & \multicolumn{2}{c}{ from [t-1] to [t+1] } & \multicolumn{2}{c}{ from [t-1] to [t+2] } \\
& difference & p-value & difference & p-value \\
\hline Control(30\%) & 0.064 & $(0.196)$ & 0.129 & $(0.116)$ \\
No Control(30\%) & -0.016 & $(0.832)$ & 0.058 & $(0.535)$ \\
Control(50\%) & $0.235^{* *}$ & $(0.005)$ & $0.293^{*}$ & $(0.023)$ \\
No Control(50\%) & -0.009 & $(0.846)$ & 0.056 & $(0.417)$ \\
\hline${ }^{*} p<0.05,{ }^{* *} p<0.01,{ }^{* * *} p<0.001$ & & &
\end{tabular}

${ }^{*} p<0.05,{ }^{* *} p<0.01,{ }^{* * *} p<0.001$ 
This is the accepted version of an article published by Elsevier in Pacific-Basin Finance Journal Vol. 46 Part A., 124140. Published version available from: https://doi.org/10.1016/j.pacfin.2017.09.007

Accepted version downloaded from SOAS Research Online: http://eprints.soas.ac.uk/24654/ under CC-BY-NC-ND 4.0 International Licence

Table 5: Descriptive statistics: Firm level

This table reports descriptive statistics of all firm-level variables including the number of ob- servations (N), mean, standard deviation (sd), minimum (min) and maximum value (max), and different quantiles (p25, p50 and p75).

\begin{tabular}{lcccccccc}
\hline & $\mathrm{N}$ & $\mathrm{mean}$ & $\mathrm{sd}$ & $\mathrm{min}$ & $\mathrm{p} 25$ & $\mathrm{p} 50$ & $\mathrm{p} 75$ & $\max$ \\
\hline ISSUE & 21349 & 0.02 & 0.15 & 0.00 & 0.00 & 0.00 & 0.00 & 1.00 \\
OPTION & 21349 & 0.08 & 0.27 & 0.00 & 0.00 & 0.00 & 0.00 & 1.00 \\
HITECH & 21349 & 0.07 & 0.26 & 0.00 & 0.00 & 0.00 & 0.00 & 1.00 \\
LEV & 21349 & 0.48 & 0.22 & 0.11 & 0.30 & 0.48 & 0.64 & 0.86 \\
SIZE & 21346 & 21.64 & 1.17 & 19.83 & 20.76 & 21.49 & 22.35 & 24.18 \\
GROWTH & 18628 & 0.15 & 0.22 & -0.17 & 0.01 & 0.10 & 0.23 & 0.74 \\
ROE & 21345 & 0.07 & 0.09 & -0.15 & 0.03 & 0.07 & 0.12 & 0.25 \\
RETURN & 20683 & 0.28 & 0.70 & -0.58 & -0.21 & 0.04 & 0.57 & 2.07 \\
COMC & 21349 & 0.32 & 0.47 & 0.00 & 0.00 & 0.00 & 1.00 & 1.00 \\
DUALITY & 17054 & 0.20 & 0.40 & 0.00 & 0.00 & 0.00 & 0.00 & 1.00 \\
BOARD & 21349 & 7.98 & 3.62 & 0.00 & 7.00 & 9.00 & 9.00 & 22.00 \\
AGE & 21344 & 47.82 & 3.47 & 0.00 & 45.62 & 47.91 & 50.08 & 61.36 \\
MANSHARE & 21345 & 0.07 & 0.17 & 0.00 & 0.00 & 0.00 & 0.00 & 0.99 \\
STATE & 21341 & 0.31 & 0.46 & 0.00 & 0.00 & 0.00 & 1.00 & 1.00 \\
HERFINDAHL & 21342 & 0.18 & 0.13 & 0.00 & 0.08 & 0.15 & 0.25 & 0.80 \\
CONTROL30 & 21349 & 0.62 & 0.48 & 0.00 & 0.00 & 1.00 & 1.00 & 1.00 \\
CONTROL50 & 21349 & 0.25 & 0.43 & 0.00 & 0.00 & 0.00 & 0.00 & 1.00 \\
ORECTA & 21188 & 0.03 & 0.06 & 0.00 & 0.00 & 0.01 & 0.03 & 0.38 \\
Q & 21349 & 1.69 & 1.34 & 0.13 & 0.69 & 1.31 & 2.30 & 5.12 \\
FIRM & 21340 & -0.00 & 0.75 & -3.25 & -0.30 & 0.06 & 0.45 & 2.34 \\
SECTOR & 21340 & 0.00 & 0.35 & -1.78 & -0.28 & 0.04 & 0.27 & 1.87 \\
LONGRUN & 21346 & 0.18 & 0.39 & -1.17 & -0.02 & 0.25 & 0.45 & 1.45 \\
\hline & & & & & & & & \\
\hline
\end{tabular}


The table reports descriptive statistics of characteristics of stock options including the num- ber of observations (N), mean, standard deviation (sd), minimum value (min), 25-percentile (p25), median (p50), 75-percentile (p75) and the maximum value (max). Panel A focuses on all newly issued stock option plans. Panel B reports the characteristics of stock options in the case of state-owned enterprises, whereas Panel C refers to companies operating in the high- technology sector.

\begin{tabular}{|c|c|c|c|c|c|c|c|c|}
\hline & $\mathrm{N}$ & mean & sd & $\min$ & p25 & p50 & p75 & $\max$ \\
\hline Panel A: & All options & & & & & & & \\
\hline SHARE & 482 & 3.31 & 2.33 & 0.00 & 1.50 & 2.81 & 4.36 & 10.78 \\
\hline EMP & 392 & 0.09 & 0.09 & 0.00 & 0.02 & 0.06 & 0.12 & 0.58 \\
\hline EXE & 482 & 0.24 & 0.22 & 0.00 & 0.09 & 0.19 & 0.35 & 1.00 \\
\hline TEC & 482 & 0.68 & 0.23 & 0.00 & 0.59 & 0.73 & 0.85 & 1.00 \\
\hline VEST & 482 & 4.92 & 1.40 & 0.00 & 4.00 & 5.00 & 5.00 & 10.00 \\
\hline MULT & 482 & 0.60 & 0.49 & 0.00 & 0.00 & 1.00 & 1.00 & 1.00 \\
\hline Panel B: & SOEs & & & & & & & \\
\hline SHARE & 52 & 1.83 & 1.89 & 0.00 & 0.82 & 1.00 & 2.36 & 9.03 \\
\hline EMP & 39 & 0.05 & 0.07 & 0.00 & 0.01 & 0.04 & 0.08 & 0.36 \\
\hline EXE & 52 & 0.36 & 0.28 & 0.00 & 0.16 & 0.28 & 0.46 & 1.00 \\
\hline TEC & 52 & 0.59 & 0.29 & 0.00 & 0.43 & 0.68 & 0.81 & 0.96 \\
\hline VEST & 52 & 6.25 & 2.02 & 4.00 & 5.00 & 5.00 & 7.00 & 10.00 \\
\hline MULT & 52 & 0.17 & 0.38 & 0.00 & 0.00 & 0.00 & 0.00 & 1.00 \\
\hline Panel C: & High-tech & & & & & & & \\
\hline SHARE & 81 & 3.36 & 1.96 & 0.31 & 2.13 & 3.00 & 4.05 & 10.00 \\
\hline EMP & 62 & 0.12 & 0.09 & 0.00 & 0.05 & 0.11 & 0.20 & 0.38 \\
\hline EXE & 81 & 0.17 & 0.18 & 0.00 & 0.05 & 0.12 & 0.25 & 1.00 \\
\hline TEC & 81 & 0.77 & 0.18 & 0.00 & 0.70 & 0.82 & 0.89 & 1.00 \\
\hline VEST & 81 & 4.73 & 1.02 & 0.00 & 4.00 & 5.00 & 5.00 & 8.00 \\
\hline MULT & 81 & 0.63 & 0.49 & 0.00 & 0.00 & 1.00 & 1.00 & 1.00 \\
\hline
\end{tabular}


Logistic regressions explain the issue of stock options. [A] focuses on firm-specific control variables including firm size (SIZE), financial leverage ( $L E V)$, growth (GROWTH ) and re-turn on equity (ROE). [B] considers stock returns prior to the issue (RETURN ) and To-bin's Q (Q). [C] decomposes Tobin's Q into firm (FIRM), industry (SECTOR) and long-run (LONGRUN) overvaluation. [D] explores the high-technology sector (HITECH) and state- ownership (STATE ). [E] considers governance mechanisms including DUALITY, remuner-ation committees (COMC), board size (BOARD), average age of executives (AGE), stock ownership of executives (MANSHARE ) and ownership concentration (HERFINDAHL).

\begin{tabular}{|c|c|c|c|c|c|}
\hline & [A] & [B] & [C] & [D] & {$[\mathrm{E}]$} \\
\hline SIZE & 0.029 & & & & \\
\hline LEV & $-2.543^{* * *}$ & & & & \\
\hline GROWTH & $1.169^{* * *}$ & & & & \\
\hline ROE & $4.197^{* * *}$ & & & & \\
\hline RETURN & & $-0.261^{* * *}$ & & & \\
\hline Q & & $0.298^{* * *}$ & & & \\
\hline FIRM & & & $0.785^{* * *}$ & & \\
\hline SECTOR & & & $0.350^{* *}$ & & \\
\hline LONGRUN & & & $0.258^{*}$ & & \\
\hline HITECH & & & & $0.934^{* * *}$ & \\
\hline STATE & & & & $-1.307^{* * *}$ & \\
\hline DUALITY & & & & & $0.378^{* * *}$ \\
\hline COMC & & & & & $0.414^{* * *}$ \\
\hline BOARD & & & & & -0.020 \\
\hline AGE & & & & & $-0.066^{* * *}$ \\
\hline MANSHARE & & & & & $2.265^{* * *}$ \\
\hline HERFINDAHL & & & & & -0.488 \\
\hline 11 & -2068.130 & -2246.140 & -2241.660 & -2222.761 & -1824.855 \\
\hline aic & 4146.259 & 4498.279 & 4491.320 & 4451.521 & 3663.709 \\
\hline bic & 4185.421 & 4522.090 & 4523.194 & 4475.427 & 3717.917 \\
\hline r2_p & 0.049 & 0.018 & 0.027 & 0.035 & 0.058 \\
\hline$N$ & 18626 & 20683 & 21340 & 21341 & 17051 \\
\hline
\end{tabular}

${ }^{*} p<0.05,{ }^{* *} p<0.01,{ }^{* * *} p<0.001$ 
The table reports logistic regressions with the timing of issues of stock options as the de- pendent variable (ISSUE ). Compared to Table 7, additional model specifications are tested. Estimation of [F] to [G] is based on the same sample size to ensure that likelihood ratio tests are valid. Model [F] starts with a general model including all explanatory variables, and [G] reduces the number of variables. Specification $[\mathrm{H}]$ refers to the reduced set of variables but applies a robust estimation to the whole sample. In addition, model [I] considers industry dummies, removing the dummy HITECH. Model $[\mathrm{J}]$ in addition to $[\mathrm{I}]$ includes year dummies. Finally, model $[\mathrm{K}]$ refers to a random effects specification.

\begin{tabular}{|c|c|c|c|c|c|c|}
\hline & {$[\mathrm{F}]$} & [G] & {$[\mathrm{H}]$} & {$[\mathrm{I}]$} & {$[\mathrm{J}]$} & {$[\mathrm{K}]$} \\
\hline SIZE & $0.311^{* *}$ & $0.239^{* * *}$ & $0.243^{* * *}$ & $0.286^{* * *}$ & $0.329^{* * *}$ & $0.334^{* * *}$ \\
\hline LEV & $-1.399^{* * *}$ & $-1.547^{* * *}$ & $-1.536^{* * *}$ & $-1.722^{* * *}$ & $-1.531^{* * *}$ & $-1.584^{* * *}$ \\
\hline GROWTH & $0.760^{* *}$ & $0.744^{* *}$ & $0.736^{* * *}$ & $0.737^{* * *}$ & $0.669^{* *}$ & $0.645^{*}$ \\
\hline ROE & $3.575^{* * *}$ & $3.504^{* * *}$ & $3.276^{* * *}$ & $3.096^{* * *}$ & $2.833^{* * *}$ & $2.890^{* * *}$ \\
\hline RETURN & -0.160 & & & & & \\
\hline FIRM & $0.295^{* *}$ & $0.225^{*}$ & $0.275^{* *}$ & $0.271^{* *}$ & $0.326^{* * *}$ & $0.330^{* *}$ \\
\hline SECTOR & -0.304 & $-0.443^{*}$ & $-0.429^{*}$ & $-0.439^{*}$ & $0.767^{*}$ & 0.757 \\
\hline LONGRUN & 0.205 & & & & & \\
\hline HITECH & $0.537^{* *}$ & $0.579^{* * *}$ & $0.574^{* * *}$ & & & \\
\hline STATE & $-0.909^{* * *}$ & $-0.985^{* * *}$ & $-0.986^{* * *}$ & $-0.884^{* * *}$ & $-0.955^{* * *}$ & $-0.936^{* * *}$ \\
\hline DUALITY & $0.324^{* *}$ & $0.333^{* *}$ & $0.329^{* *}$ & $0.308^{* *}$ & $0.305^{*}$ & $0.309^{*}$ \\
\hline COMC & $0.275^{* *}$ & $0.282^{* *}$ & $0.282^{* *}$ & $0.283^{* *}$ & $0.230^{*}$ & $0.231^{*}$ \\
\hline BOARD & -0.028 & & & & & \\
\hline AGE & $-0.083^{* * *}$ & $-0.082^{* * *}$ & $-0.081^{* * *}$ & $-0.079^{* * *}$ & $-0.082^{* * *}$ & $-0.085^{* * *}$ \\
\hline MANSHARE & $1.773^{* * *}$ & $1.795^{* * *}$ & $1.810^{* * *}$ & $1.658^{* * *}$ & $1.575^{* * *}$ & $1.616^{* * *}$ \\
\hline HERFINDAHL & -0.736 & & & & & \\
\hline 11 & -1604.225 & -1607.476 & -1610.647 & -1584.854 & -1543.972 & -1542.542 \\
\hline aic & 3242.449 & 3240.952 & 3247.294 & 3223.709 & 3155.945 & 3155.083 \\
\hline bic & 3371.886 & 3339.933 & 3346.540 & 3429.350 & 3412.612 & 3419.299 \\
\hline r2_p & 0.120 & 0.118 & 0.120 & 0.131 & 0.140 & \\
\hline$N$ & 14972 & 14972 & 15280 & 15008 & 14031 & 14031 \\
\hline
\end{tabular}

${ }^{*} p<0.05,{ }^{* *} p<0.01,{ }^{* * *} p<0.001$ 
This is the accepted version of an article published by Elsevier in Pacific-Basin Finance Journal Vol. 46 Part A., 124140. Published version available from: https://doi.org/10.1016/j.pacfin.2017.09.007

Accepted version downloaded from SOAS Research Online: http://eprints.soas.ac.uk/24654/ under CC-BY-NC-ND 4.0 International Licence

Table 9: Model specifications for non-SOEs with and without controlling shareholder

The table reports logistic regressions of the general model for the non-SOE subgroups based on the two thresholds of $30 \%$ and 50\%. [F1] and [F2] refer to non-SOEs with and without controlling shareholders based on the 30\% threshold. [F3] and [F4] apply the $50 \%$ threshold.

\begin{tabular}{|c|c|c|c|c|}
\hline & \multicolumn{2}{|c|}{$30 \%$} & \multicolumn{2}{|c|}{$50 \%$} \\
\hline & {$[\mathrm{F} 1]$} & {$[\mathrm{F} 2]$} & [F3] & {$[\mathrm{F} 4]$} \\
\hline SIZE & 0.020 & $0.717^{* * *}$ & 0.022 & $0.434^{* * *}$ \\
\hline LEV & $-1.376^{* *}$ & $-1.274^{*}$ & -0.695 & $-1.590^{* * *}$ \\
\hline GROWTH & 0.612 & $0.872^{*}$ & 0.503 & $0.779^{* *}$ \\
\hline ROE & $3.672^{* *}$ & $2.930^{*}$ & 1.934 & $3.596^{* * *}$ \\
\hline RETURN & -0.075 & -0.218 & -0.430 & -0.089 \\
\hline FIRM & 0.241 & $0.459^{*}$ & 0.571 & $0.286^{*}$ \\
\hline SECTOR & -0.411 & -0.335 & 0.588 & $-0.550^{*}$ \\
\hline LONGRUN & -0.315 & 0.959 & -0.741 & 0.526 \\
\hline HITECH & $0.550^{*}$ & 0.499 & 0.437 & $0.512^{* *}$ \\
\hline DUALITY & $0.318^{*}$ & $0.385^{*}$ & 0.427 & $0.295^{*}$ \\
\hline COMC & $0.342^{*}$ & 0.009 & 0.408 & 0.162 \\
\hline BOARD & -0.058 & 0.019 & -0.074 & -0.009 \\
\hline AGE & $-0.085^{* * *}$ & $-0.094^{* * *}$ & $-0.119^{* *}$ & $-0.084^{* * *}$ \\
\hline MANSHARE & $1.472^{* * *}$ & $2.189^{* * *}$ & $1.634^{* *}$ & $1.937^{* * *}$ \\
\hline HERFINDAHL & -0.337 & 1.895 & 1.216 & -0.257 \\
\hline 11 & -819.312 & -543.487 & -250.093 & -1114.344 \\
\hline aic & 1670.623 & 1118.974 & 532.186 & 2260.689 \\
\hline bic & 1777.096 & 1221.521 & 621.097 & 2373.092 \\
\hline r2_p & 0.097 & 0.128 & 0.119 & 0.107 \\
\hline$N$ & 5736 & 4488 & 1914 & 8310 \\
\hline
\end{tabular}

${ }^{*} p<0.05,{ }^{* *} p<0.01,{ }^{* * *} p<0.001$ 
Table 10: Treated, matched and unmatched sample

The table reports descriptive statistics of variables that explain the adoption of stock options for the treatment group (Panel A), the matched control group (Panel B), and the unmatched sample (Panel C). Descriptive statistics include the number of observations (N), mean, stan-dard deviation (sd), minimum value (min), 25-percentile (p25), median (p50), 75-percentile (p75) and the maximum value (max).

\begin{tabular}{|c|c|c|c|c|c|c|c|c|}
\hline & $\mathrm{N}$ & mean & sd & $\min$ & p25 & p50 & p75 & $\max$ \\
\hline Panel A & Treated & & & & & & & \\
\hline ISSUE & 396 & 0.99 & 0.07 & 0.00 & 1.00 & 1.00 & 1.00 & 1.00 \\
\hline SIZE & 396 & 21.58 & 1.05 & 19.83 & 20.78 & 21.37 & 22.23 & 24.18 \\
\hline LEV & 396 & 0.38 & 0.20 & 0.11 & 0.20 & 0.34 & 0.53 & 0.86 \\
\hline GROWTH & 396 & 0.22 & 0.22 & -0.17 & 0.07 & 0.15 & 0.34 & 0.74 \\
\hline ROE & 396 & 0.10 & 0.06 & -0.15 & 0.07 & 0.10 & 0.14 & 0.25 \\
\hline FIRM & 396 & 0.31 & 0.53 & -2.57 & -0.03 & 0.32 & 0.69 & 1.86 \\
\hline SECTOR & 396 & 0.02 & 0.27 & -0.54 & -0.14 & 0.02 & 0.14 & 1.15 \\
\hline HITECH & 396 & 0.17 & 0.37 & 0.00 & 0.00 & 0.00 & 0.00 & 1.00 \\
\hline STATE & 396 & 0.11 & 0.31 & 0.00 & 0.00 & 0.00 & 0.00 & 1.00 \\
\hline DUALITY & 396 & 0.35 & 0.48 & 0.00 & 0.00 & 0.00 & 1.00 & 1.00 \\
\hline COMC & 396 & 0.42 & 0.49 & 0.00 & 0.00 & 0.00 & 1.00 & 1.00 \\
\hline AGE & 396 & 46.33 & 3.29 & 37.15 & 43.93 & 46.22 & 48.74 & 55.63 \\
\hline MANSHARE & 396 & 0.22 & 0.24 & 0.00 & 0.00 & 0.07 & 0.44 & 0.85 \\
\hline Panel B & Matched & & & & & & & \\
\hline ISSUE & 1661 & 0.00 & 0.00 & 0.00 & 0.00 & 0.00 & 0.00 & 0.00 \\
\hline SIZE & 1661 & 21.62 & 1.10 & 19.83 & 20.80 & 21.46 & 22.32 & 24.18 \\
\hline LEV & 1661 & 0.39 & 0.21 & 0.11 & 0.21 & 0.37 & 0.56 & 0.86 \\
\hline GROWTH & 1661 & 0.21 & 0.24 & -0.17 & 0.05 & 0.14 & 0.30 & 0.74 \\
\hline $\mathrm{ROE}$ & 1661 & 0.10 & 0.07 & -0.15 & 0.05 & 0.10 & 0.15 & 0.25 \\
\hline FIRM & 1661 & 0.28 & 0.57 & -2.93 & -0.09 & 0.26 & 0.66 & 2.33 \\
\hline SECTOR & 1661 & 0.01 & 0.31 & -1.70 & -0.14 & 0.03 & 0.17 & 1.17 \\
\hline НITECH & 1661 & 0.14 & 0.35 & 0.00 & 0.00 & 0.00 & 0.00 & 1.00 \\
\hline STATE & 1661 & 0.11 & 0.31 & 0.00 & 0.00 & 0.00 & 0.00 & 1.00 \\
\hline DUALITY & 1661 & 0.30 & 0.46 & 0.00 & 0.00 & 0.00 & 1.00 & 1.00 \\
\hline
\end{tabular}


This is the accepted version of an article published by Elsevier in Pacific-Basin Finance Journal Vol. 46 Part A., 124140. Published version available from: https://doi.org/10.1016/j.pacfin.2017.09.007

Accepted version downloaded from SOAS Research Online: http://eprints.soas.ac.uk/24654/ under CC-BY-NC-ND 4.0 International Licence

\begin{tabular}{lcccccccc} 
COMC & 1661 & 0.44 & 0.50 & 0.00 & 0.00 & 0.00 & 1.00 & 1.00 \\
AGE & 1661 & 46.68 & 3.97 & 0.00 & 44.50 & 46.85 & 48.89 & 58.31 \\
MANSHARE & 1661 & 0.19 & 0.24 & 0.00 & 0.00 & 0.00 & 0.39 & 0.89 \\
\hline Panel C & Unmatched & & & & & & & \\
\hline ISSUE & 20867 & 0.00 & 0.00 & 0.00 & 0.00 & 0.00 & 0.00 & 0.00 \\
SIZE & 20864 & 21.64 & 1.17 & 19.83 & 20.76 & 21.49 & 22.35 & 24.18 \\
LEV & 20867 & 0.48 & 0.22 & 0.11 & 0.31 & 0.49 & 0.64 & 0.86 \\
GROWTH & 18163 & 0.14 & 0.22 & -0.17 & 0.00 & 0.10 & 0.23 & 0.74 \\
ROE & 20863 & 0.07 & 0.09 & -0.15 & 0.03 & 0.07 & 0.12 & 0.25 \\
FIRM & 20858 & -0.01 & 0.75 & -3.25 & -0.31 & 0.05 & 0.45 & 2.34 \\
SECTOR & 20858 & -0.00 & 0.35 & -1.78 & -0.29 & 0.04 & 0.27 & 1.87 \\
HITECH & 20867 & 0.07 & 0.25 & 0.00 & 0.00 & 0.00 & 0.00 & 1.00 \\
STATE & 20859 & 0.32 & 0.47 & 0.00 & 0.00 & 0.00 & 1.00 & 1.00 \\
DUALITY & 16643 & 0.20 & 0.40 & 0.00 & 0.00 & 0.00 & 0.00 & 1.00 \\
COMC & 20867 & 0.32 & 0.47 & 0.00 & 0.00 & 0.00 & 1.00 & 1.00 \\
AGE & 20862 & 47.85 & 3.47 & 0.00 & 45.67 & 47.94 & 50.11 & 61.36 \\
MANSHARE & 20863 & 0.07 & 0.16 & 0.00 & 0.00 & 0.00 & 0.00 & 0.99 \\
\hline
\end{tabular}


This is the accepted version of an article published by Elsevier in Pacific-Basin Finance Journal Vol. 46 Part A., 124140. Published version available from: https://doi.org/10.1016/j.pacfin.2017.09.007

Accepted version downloaded from SOAS Research Online: http://eprints.soas.ac.uk/24654/ under CC-BY-NC-ND 4.0 International Licence

Table 11: The impact of stock options on performance

\begin{tabular}{|c|c|c|c|c|c|c|}
\hline Variable & Sample & Treated & Controls & Difference & Std & t-value \\
\hline \multirow[t]{2}{*}{ ROE } & Unmatched & 0.099 & 0.071 & 0.028 & 0.003 & 10.97 \\
\hline & ATT & 0.099 & 0.099 & 0.000 & 0.002 & -0.04 \\
\hline \multirow[t]{2}{*}{ GROWTH } & Unmatched & 0.210 & 0.140 & 0.070 & 0.006 & 11.15 \\
\hline & ATT & 0.210 & 0.208 & 0.002 & 0.007 & 0.23 \\
\hline \multirow[t]{2}{*}{ RETURN } & Unmatched & 0.256 & 0.316 & -0.060 & 0.022 & -2.72 \\
\hline & ATT & 0.255 & 0.270 & -0.015 & 0.023 & -0.64 \\
\hline
\end{tabular}

